\title{
Customer Sustainable Maintenance Model to Increasing Traditional Retails Competitiveness in Dealing with Minimarket Expansion
}

\author{
Sunaryati Hardiani Nanik Sisharini \\ Faculty of Economics and Business University of Merdeka Malang J1. Terusan Raya Dieng 62-64 Malang \\ East Java - Indonesia
}

\begin{abstract}
Indonesia is a potential market for modern retail business, supported by the shifting behavior of Indonesians from shopping in traditional markets to modern retailers. The main objective of this research is to find modern retail management model to improve the competitiveness of traditional retails in customer service field. Research method using descriptive research method and policy research. The unit analysis is traditional Retail Traders and Modern retail traders in Blitar District. Data analysis techniques use descriptive analysis to describe findings and policies that involve interested parties to get the right model. The research results show there are 248 modern retail and 2,401 traditional retailers. To be able to compete with modern retail, traditional retail should be cleaned up by doing service plus plus with aim to sustainable maintenance of customer to remain faithful as customer. Service plus plus which is intended is the customer to buy goods do not have to come directly to the store, but can be done with Purchase Order by WhatsApp or SMS, Delivery Service, and Pay After the goods delivered.
\end{abstract}

Keywords: Traditional RetailS, Service Plus Plus and Sustainable Maintenance Model

\section{Introduction}

The word retail comes from the French ritellier which means to cut or break something. Ritail or retail (retailing) can be defined as all activities in the sale of goods or services directly to the end consumer for personal use and not a business use. In general, the definition of retailers or retailers is the last link in the distribution process, (Thoyib, 1998: 1). The management of the retail business is not just about opening a store and preparing complete items, but a retail business should see and follow the development of marketing technology to succeed and have competitive advantage.

The development of retail business in Indonesia today is very rapid, especially modern retailers in all variations of its type. Several factors supporting the development of modern retail business include the opening of market opportunities, the development of manufacturing business that will supply its products to the retailer, and the government's efforts to boost economic growth by one of them developing the retail business. Based on data from the Association of Indonesian Retail Companies from 2007-2012, the number of modern retail outlets in Indonesia an average growth of $17.57 \%$ per year. In 2007 , the number of retail business in Indonesia is still 10,365 outlets, then in 2011 reached 18,152 outlets spread in almost all cities in Indonesia. The growth of number of outlets is of course followed by sales growth. The amount of retail business growth in Indonesia is between 10\% -15\% per year. Retail sales in 2006 stood at Rp 49 trillion, and shot up to Rp120 trillion in 2011. While in 2012, retail growth is projected to remain the same, which is $10 \%-15 \%$, or reach Rp.138 trillion.

The number of players in the retail business makes the competition very tight. Major retailers, especially foreign companies, are increasingly aggressively expanding their business in Indonesia. Small modern retailers and traditional retailers become unfavorable parties. Indonesia with a population about 237 million people with a total consumptiont Rp3,600 trillion is a potential market for modern retail business. This is supported by the shifting behavior of the Indonesian population, from shopping in traditional markets to modern retailers. With the opening of entrances for foreign retailers as Presidential Decree no. 118/2000 which has issued retail business from negative list for foreign investment (PMA), foreign retail began to bloom into Indonesia. The entry of foreign retailers in the business shows this business is very profitable. On the other hand, the expansion of foreign hypermarkets expanding their network of outlets, could pose a threat to local retailers.

Traditional retail located in rural areas and people's settlements were affected by dealing directly with the modern retailer. Competition between the two was not avoided. Not only that, due to the lack of zoning rules from the modern retail development, the traditional retailers in big cities are affected. Competition head to head due to the proliferation of modern retailers have a negative impact on the existence of traditional retail. One of the real impacts of modern retail presence in the midst of traditional retail is the decrease in the number of small traders and the decline of turnover from small traders, therefore traditional retailers need to be equipped with modern retail management science in order to have competitiveness.

The existence of traditional retailers is still quite necessary in the context of serving the lower economic segment. However, technological advancement and the increasing demands of consumer needs are the driving 
force behind business-oriented changes in retail business. If initially many retail businesses are fairly traditionally managed, without adequate technological support, without a modern management approach and without focusing on comfort and desire to meet customer needs. The shifting behavior patterns of customer purchases detected from a number of studies conducted show that customer shopping activities not only in an effort to meet the needs of goods for life, but rather lead to the fulfillment of the need for recreation. This condition encourages the traditional retail business to begin to be sensitive to the needs of unmet customers if they want to survive in an increasingly competitive retail business environment.

An understanding of the concepts of modern retail management is very important to understand, given the failure in management will incur considerable risk of loss, if a retail businessman survives with traditional retail management it is not possible to have a sustainable competitive advantage when the increasing number of modern retailers managed with substantial capital as well as changes in consumer spending patterns that have consequences for changing needs the existence of a retail. Therefore, it is important to develop the knowledge and skills in the field of retail management that will increase the readiness of traditional retail managers in implementing all the knowledge and concepts of modern retail management in an integrated manner, especially for the readiness to manage modern retail business of small and medium sized independently. The main objective of this research is to find modern retail management model to improve the competitiveness of traditional retail traders in the field of consumer services, and specific targets to be achieved from this research are Improved services to consumers to facilitate and accelerate the process of purchasing goods needed and Increased competitiveness Traditional retail traders against modern retailers. So the background of this research shows as the figure 1 .

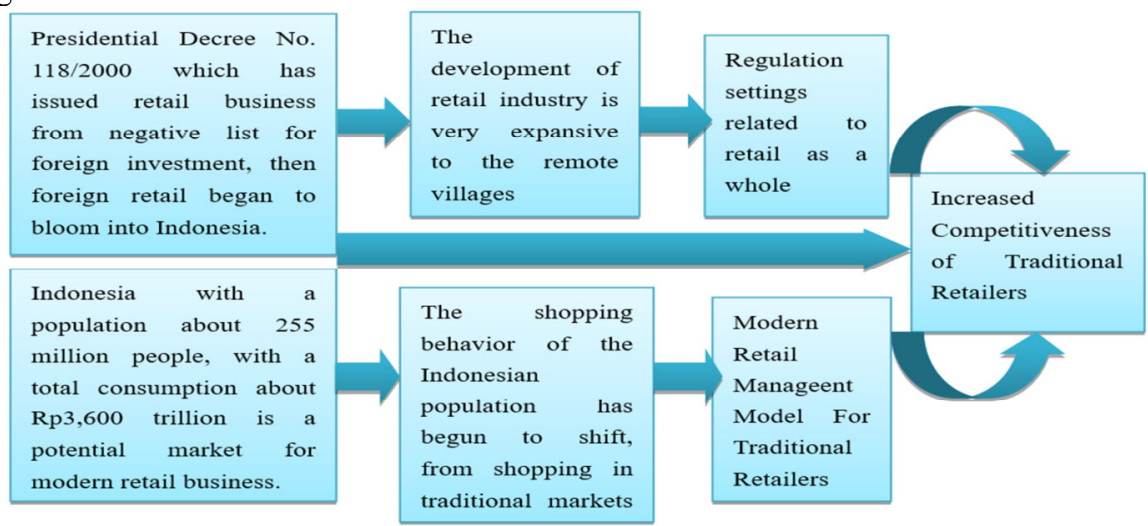

Figure 1. Research Background

\subsection{Relevant Research}

Based on the results of research from Soliha (2008) who conducted research on the analysis of retail industry in Indonesia can be concluded that there is a very strong competition between traditional retailers with modern retailers, and between local retailers with foreign retailers. In addition buyers have a strong position to make choices because of the many retail outlets offered and the pattern of changes in consumption. The results of this study indicate that in order to compete with modern retailers, the traditional retailers have to increase the service to the consumers in order to have competence to survive in the retail business (continuous competitive advantage) in accordance with retail mix theory from Utami (2006) from the five elements of Place, People, Product, Price, Promotion. Supiatni (2012) examines the Consumer Assessment on the Application of Retail Marketing Mix, the results show that in choosing where to shop consumers are very concerned about the marketing mix adopted by retailers. Supiatni's research results support the theory of retail mix from Utami (2006). The research results of Utomo (2010) on Business Environment and Business Competition Retail supports research result from Soliha (2008) where in the retail business there is a direct competition between traditional retail with modern retail, between traditional retail fellow, between modern retail and added competition between supplier. Unbalanced competition occurs between traditional retailers and modern retailers who have advantages such as comfortable conditions, clean, good service and the availability of complete and quality goods.

\section{Research Methods}

The design of this study is a combination of descriptive research, and applied research. The unit of analysis is 1) Traditional retail traders in Kab. Blitar. 2) Modern retail traders in Kab. Blitar 3) Department of Trade and Industry Kab. Blitar. The population of this study is retail traders in Kab. Blitar, determining the number of samples by using slovin formula and based on purposive sampling. Data collection techniques with questioner, interview and FGD dissemination. Data analysis techniques use descriptive analysis to describe the findings and get the right model, and the research stage shows as the figure 2 . 


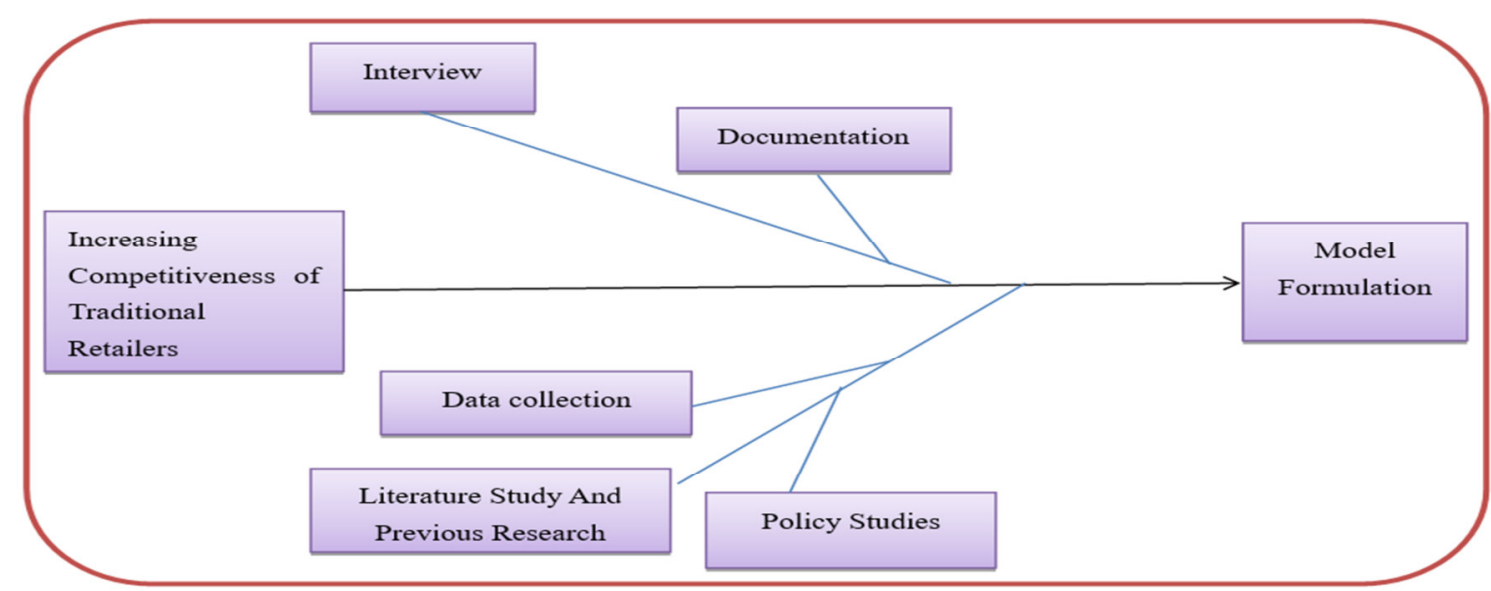

Figure 2. Research Stages

Details of the research stages in accordance with the drawings of the research stages is to develop a modern retail management model for traditional retailers with the following steps:

a. Literature study and policy of Local Government of Blitar district related to the existence of increasingly number of minimarket.

b. Data collection from traditional retails and modern retails with questionnaires about identification of services to consumers.

c. Data analysis

d. Modeling.

\section{Research Result}

Blitar district consists of 22 subdistricts and 248 villages. Based on the slovin formula the number of each sample of the study as follows: 96 for traditional retail and 76 for modern retail. In Blitar district the existence of modern retail has been arranged with Perda No 17/2011 franchise distance with traditional market at least 1 kilometer. Franchising is also required to fill $1 \%$ of merchandise with local products.

Data on the number of traditional retail and modern retail in Blitar district are shown in the following table:

\begin{tabular}{|c|c|c|c|c|}
\hline \multirow[t]{2}{*}{ No. } & \multirow[t]{2}{*}{ Subdistricts Name } & \multirow{2}{*}{$\begin{array}{c}\text { Number of } \\
\text { Villages }\end{array}$} & \multicolumn{2}{|c|}{ Number Of Retails } \\
\hline & & & Tradistonal & Modern \\
\hline 1 & Bakung & 11 & 115 & 12 \\
\hline 2 & Binangun & 12 & 98 & 14 \\
\hline 3 & Doko & 10 & 110 & 15 \\
\hline 4 & Gandusari & 14 & 116 & 13 \\
\hline 5 & Garum & 9 & 111 & 12 \\
\hline 6 & Kademangan & 15 & 135 & 23 \\
\hline 7 & Kanigoro & 12 & 120 & 16 \\
\hline 8 & Kesamben & 10 & 98 & 13 \\
\hline 9 & Nglegok & 11 & 112 & 14 \\
\hline 10 & Panggungrejo & 10 & 96 & 11 \\
\hline 11 & Ponggok & 15 & 124 & 25 \\
\hline 12 & Sanan Kulon & 12 & 108 & 16 \\
\hline 13 & Selopuro & 8 & 102 & 25 \\
\hline 14 & Selorejo & 10 & 105 & 15 \\
\hline 15 & Srengat & 16 & 116 & 18 \\
\hline 16 & Sutojayan & 11 & 102 & 14 \\
\hline 17 & Talun & 14 & 109 & 16 \\
\hline 18 & Udanawu & 12 & 120 & 10 \\
\hline 19 & Wates & 8 & 90 & 6 \\
\hline 20 & Wlingi & 9 & 122 & 10 \\
\hline 21 & Wonodadi & 11 & 104 & 13 \\
\hline 22 & Wonotirto & 8 & 88 & 10 \\
\hline & Jumlah & 248 & 2.401 & 321 \\
\hline
\end{tabular}

Figure 3 Number of Traditional Retail And Modern Retail In Blitar District

In the fact the local regulation has been violated mainly in terms of distance, so that the existence of 
traditional retailers is threatened. Traditional retail traders are a manifestation of populist economy. In business the traditional retail traders are the middle to lower economic group. For traditional retailers, the presence of modern retailers with all the advantages is a serious threat.

\section{Discussion}

\subsection{Traditional Retail and Modern Retail}

Various terms of retail are as follows: Ma'ruf (2005: 7) defines retail is a business activity selling goods or services to individuals for the purposes of self, family or household. According to Kotler (2003: 535) retail includes all activities involving the sale of goods or services directly to the end consumer for personal and nonbusiness use. Meanwhile, according to Berman and Ervans (2002: 3) the definition of retail is the last level of the distribution process, in which there is business activity in the sale of goods or services to consumers. And according to Gilbert (2003: 6) retail is all business ventures that direct direct marketing ability to satisfy the final consumer based on the organization of goods and services sales as the core of the distribution.

From the above, in general, the definition of retail is any activity of trading of goods or services to end consumers for their own use, not for trading anymore. Retail is one of the chain of distribution channels that plays an important role in the delivery of goods and services to the final consumer. Retail includes all activities that involve the sale of goods or services directly to the final consumer for personal and non-business use. Retail not only sells products in stores, but retail also involves delivery services to homes. Not all retail is done in stores.

Activities undertaken in retail business is to sell various products, services or both, to consumers for personal and joint consumption purposes. Manufacturers sell their products to retailers and large retailers (wholesaler). These large retailers are also often referred to as wholesalers or wholesalers. The retail industry is constantly changing along with technological changes, the development of the business world, and of course the needs of consumers. Retail is the entire business activity associated with the sale and delivery of services to the consumer for the use of an individual nature as a person or family. In order to succeed in a competitive retail market, retailers must be able to offer the right product, at the right price, at the right place, and at the right time. Therefore, the understanding of retailers tehadap characteristics of target markets or consumers to be served is very important. In its operations retailers perform several functions, among others, assist consumers in providing various products and services, run the function of breaking (bulk breaking), and add product value. Overall, the management of retail business requires the implementation of management functions in an integrated manner in terms of financial, marketing, human resources, and operational functions.

The basic concept of retail management according to Thoyib (1998: 15) includes: 1) Orientation On Consumers that retailers must determine the attributes and needs of consumers and are willing to meet the needs of consumers, 2) Coordinated Enterprises that retailers must integrate all the plans and activities to maximize efficiency, and 3) Orientation In Purpose that retailers must establish goals and define strategies to achieve those goals. Based on data from the Association of Indonesian Retail Entrepreneurs retail business in Indonesia began to develop in the 1980s along with the development of the Indonesian economy, and accompanied by an increase in the number of middle-class society followed by lifestyle changes that prefer shopping in modern shopping centers. Changes in spending patterns is not just to meet the needs of shopping, but also the streets for entertainment.

Retail industry in Indonesia is increasingly growing with the development of new outlets in various places. Broadly speaking, retail business focusing on the sale of everyday goods is divided into two, namely traditional retail business and modern retail business. The characteristics of traditional retail business is simple, the place is not too broad, the goods are sold not too many types, the management system / management is still simple, does not offer the convenience of shopping and there is a process of bargaining prices with merchants, and products sold are not on display openly so that the customer does not know whether the retailer has the goods sought or not. While the modern retail business is the opposite, offering a wide range of goods, many types of goods sold, well managed management system, offering convenience shopping, fixed price price so there is no bargaining process and self-service system, as well as displaying products on open shelves so that customers can see, choose, and even try the product first before deciding to buy.

The change of retail business management from traditional retail to modern retail is indispensable as the consumer paradigm shifts in buying goods to meet the needs of life. Most retail businesses in Indonesia are small and medium enterprises with traditional retail management. As the consumer paradigm changes, it is necessary to align the changes of traditional retail services into a modern retail management system. Modern retail management requires adequate infrastructure support, especially technology needs. Technological support is necessary because to facilitate faster, more accurate, satisfactory service and inventory control in the warehouse.

\subsection{Consumer Service Model Traditional Retails}

In order to compete with modern retailers, traditional retailers must be able to provide better service. One of the 
efforts to provide better service is by utilizing the existing technology today. The first step in traditional retailers' efforts to compete with modern retailers is to classify consumers as shown in figure below.

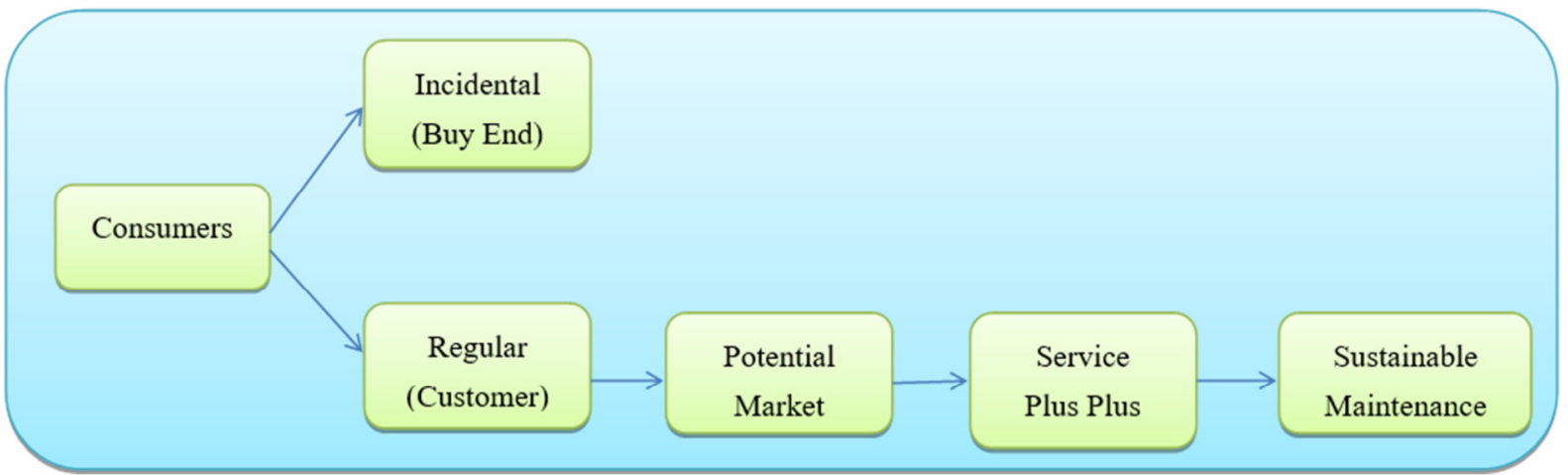

Expanation :

Figure 4 Consumer Clasification

Consumers are divided into 2 namely:

a. Incidental (Buy Disconnect) means that the consumer is not a person living in a location and not a customer.

b. Regular (Customer) means the consumer is usually a person who lives around the retail location, and often shopping needs that are routine.

c. Regular consumers are potential market for traditional retail, therefore needed service plus plus as effort for sustainable maintenance by utilizing existing technology at this time. Sustainable maintenance model is needed so that this customer remains a loyal customer.

Customer Sustainable Maintenance model is a customer service model based on the utilization of mobile technology that is now very familiar used the sms and whatsApp (WA) feature. What needs to be prepared and is new to traditional retailers is the fleet delivery service. Procedure on customer sustainable maintenance model is traditional retail must have customer data base consisting of name and mobile phone number and certain stock of customer requirement goods always available. Purchase order is done through WA or SMS then the goods are sent and paid after the goods received by the customer. With the service plus-plus is expected to arise customer loyalty to traditional retailers.

Sustainable Maintenance Model Traditional retail traders as an effort to maintain customer loyalty are described in the following figure.

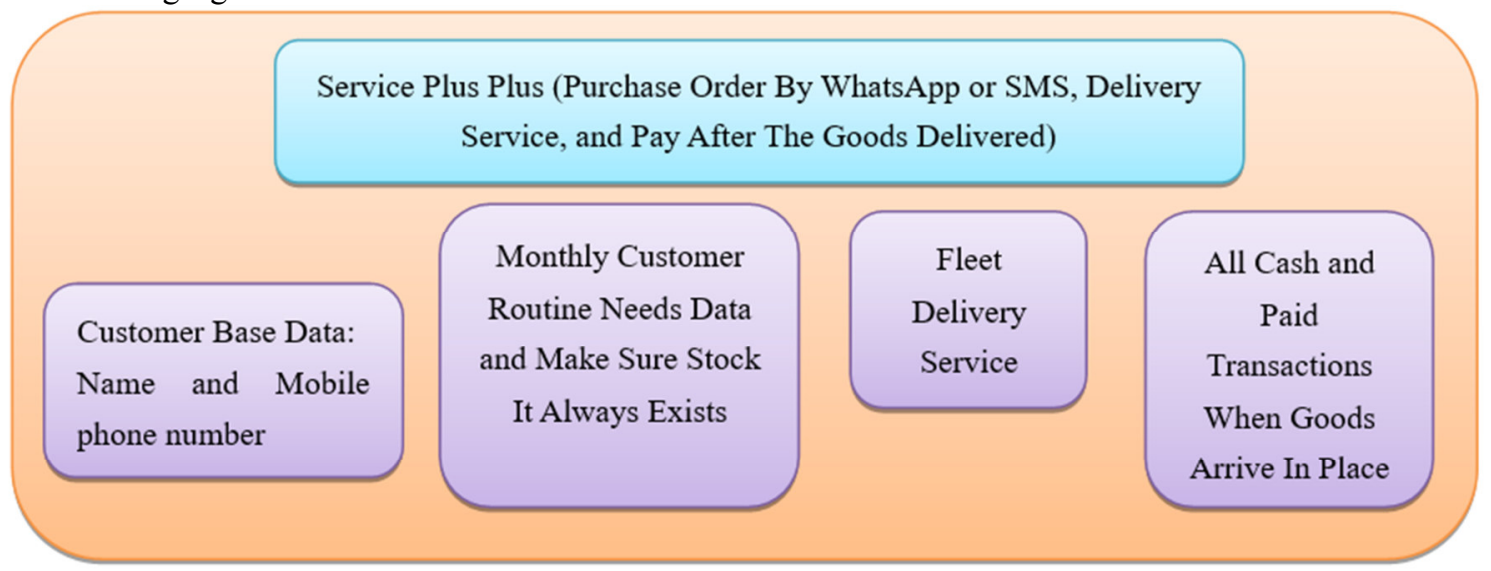

Figure 5 Customer Sustainable Maintenance Model

\section{Conclusion And Suggestion}

\subsection{Conclusions}

1. The number of modern retail traders in Blitar district threatens the existence of traditional retail, although based on Perda No 17/2011 franchise distance with traditional market at least 1 kilometer but this rule has not been implemented.

2. To competition between traditional retailers and modern retailers, traditional retailers inevitably have to tidy up customer service by utilizing technology.

\subsection{Suggestion}

1. The existence of firmness in the implementation of Regulation No. 17/2011 of Blitar District, so 
that the existence of traditional retail traders is protected from the attack of modern retail presence.

2. The need for improved services to consumers by traditional retailers so that customers do not switch to other traders.

\section{References}

Amir, M Taufiq. 2004. Retail Management. Jakarta. Publisher PPM.

Berman, Barry dan Joel R. Evans. 2007. Retail Manajemen. New Jersey: Prentice Hall.

Doherty, A.M. and Quinn. B. 1999. International retail franchising: an agencu theory perspective. International Journal Of Retail \& Distribution Management. Vol. 27, No. 6, pp. 224-236.

Gilbert. 2003. Retail Trading in Indonesia. Bandung: PT Citra Aditya Bakti.

Indef. 2007. Economic Impact Assessment of Hypermarket Presence on Retail / Traditional Markets: Executive Summary. Cooperation with Puslitbang Domestic Trade Ministry of Trade RI

Levy, Michael dan Barton. 1995. Retailing Management, 2nd edition. Richard D. Irwin, Inc.

Lucas, Bush dan Gresham. 1994. Development of Retail Industry in Indonesia Jakarta: PT. Kualamas.

Ma'ruf, Hendri. 2006. Retail Marketing Jakarta: PT gramedia Pustaka Utama.

Media Promosi Bisnis. Media Promotion Business 2016. elopment of Modern Retail Business In Indonesia. 20 Januari.

Pintel ,G and Diamond, J. 1971. Retailing. 5th.ed.New Jersey: Pretice Hall.

Risch, Ernest H. 1991. Retail merchandising. USA: Mac. Millan Publishing Company.

Sudjana, Asep ST. 2005. New Paradigm In Modern Retail Management Yogyakarta: Publisher Graha Ilmu

Soliha, Euis. 2008. Retail Industry Analysis In Indonesia. Journal of Business and Economics.September, Vol. 15 No. 2 Hal. 128-142.

Supiatni, Ni Nyoman. 2012. Consumer Assessment on the Application of Retail Marketing Mix at Fresh Fruit Store Denpasar. Journal of Business and Entrepreneurship. Maret, Vol. 8, No. 1.

Tambunan, TulusTH, dkk. 2004. Review of Competition in the Retail Industry. Commission for the Supervision of Business Competition

Thoyib, Usman. 1998. Retail Trade Management. Retail Trade Management Yogyakarta: Publisher Ekonisia

Utami, Christina Whidya. 2008. Ritel Management of Merchandise in Retail Businesses.. Publisher Bayu Media No. ISBN 978-979-3323-93-0

Utami, Christina Whidya. 2010. Retail Management: Strategy and Implementation of Modern Retail Business Operations in Indonesia. Edisi ke 2. Jakarta: Publisher Salemba Empat.

Utomo, Tri Joko. 2010. Lingkungan Bisnis Dan Persaingan Bisnis Ritel. Jurnal Fokus Ekonomi. Business Environment And Business Competition Retail. Journal of Economic Focus.Vol. 5 No. 1. June. p. 70-80 